\title{
NMDA Receptor Agonists Fail To Alter Release from Cerebellar Basket Cells
}

\author{
Jason R. Pugh and Craig E. Jahr \\ Vollum Institute, Oregon Health \& Science University, Portland, Oregon 97239
}

Previous studies of NMDA receptor (NMDAR) expression on axons of cerebellar molecular layer interneurons have produced conflicting results. We made use of the calcium sensitivity of vesicular release machinery to test for NMDAR activity in basket cell axons. Iontophoresis of $\mathrm{L}$-aspartate, an NMDAR agonist, onto basket cell axon collaterals had no effect on evoked IPSCs measured in synaptically coupled Purkinje cells. Furthermore, calcium indicators in basket cell varicosities did not report any change in intracellular calcium following iontophoresis of L-aspartate or two-photon uncaging of glutamate. In contrast, activation of presynaptic purinergic receptors by iontophoresis of ATP decreased evoked IPSC amplitudes and action potential-evoked calcium transients in axonal varicosities, demonstrating the effectiveness of activating presynaptic receptors by iontophoresis. We find no evidence for functional NMDARs in basket cell varicosities.

\section{Introduction}

Postsynaptic NMDA receptors (NMDARs) are important mediators of synaptic transmission and plasticity (Bliss and Collingridge, 1993). The calcium permeability and voltagedependent block by $\mathrm{Mg}^{2+}$ of NMDARs make them ideally suited to mediate coincidence detection of presynaptic and postsynaptic events and effect changes in synaptic strength. A growing number of studies report that NMDARs are also expressed on presynaptic terminals, where they modulate release (Glitsch and Marty, 1999; Brasier and Feldman, 2008; McGuinness et al., 2010; Larsen et al., 2011) and/or are required for induction of long-term depression (Sjöström et al., 2003; Bender et al., 2006; Rodríguez-Moreno et al., 2011). However, efforts to observe axonal calcium transients or conductance increases mediated by presynaptic NMDAR activation have failed in several cell types (Clark and Cull-Candy, 2002; Christie and Jahr, 2008, 2009).

In particular, studies of axonal NMDARs in cerebellar molecular layer interneurons (MLIs), consisting of stellate and basket cells, have produced conflicting results. Bath application of NMDA increases spontaneous IPSC frequency in Purkinje cells and MLIs, but decreases evoked IPSC amplitudes (Glitsch and Marty, 1999; Glitsch, 2008). Duguid and Smart (2004) showed that sustained depolarization of Purkinje cells $(0 \mathrm{mV}, 3-5 \mathrm{~s})$ produces a 5-10 min increase in spontaneous IPSC frequency [depolarization induced potentiation of inhibition (DPI)] blocked by bath application of D-AP5, but did not assess changes in evoked release. On the other hand, local application of aspartate

Received July 29, 2011; revised Sept. 16, 2011; accepted Sept. 21, 2011.

Author contributions: J.R.P. and C.E.J. designed research; J.R.P. performed research; J.R.P. analyzed data; J.R.P. and C.E.J. wrote the paper.

This work was supported by NIH Grant NS066037 (C.E.S.) and a Tartar Trust fellowship (J.R.P.). We thank the Jahr laboratory members for discussions and critical readings of the manuscript.

Correspondence should be addressed to Craig E. Jahr, Vollum Institute, L474, OHSU, 3181 SW Sam Jackson Park Road, Portland, OR 97239. E-mail: jahr@ohsu.edu.

DOI:10.1523/JNEUROSCI.3910-11.2011

Copyright $\odot 2011$ the authors $\quad 0270-6474 / 11 / 3116550-06 \$ 15.00 / 0$ or glutamate onto MLI axons activates neither calcium transients nor currents, suggesting that NMDARs are not expressed on these axons (Clark and Cull-Candy, 2002; Christie and Jahr, 2008).

In light of the conflicting reports regarding NMDAR expression in MLI axons, we looked for direct evidence of NMDARs on basket cell axons. Our motivation for using basket cells was twofold. First, while most reports of presynaptic NMDAR expression do not distinguish between basket and stellate cells (Glitsch and Marty, 1999; Duguid and Smart, 2004; Glitsch, 2008), the best evidence of their expression is in basket terminals (Duguid et al., 2007). Christie and Jahr (2008), on the other hand, mainly looked for evidence of NMDARs in stellate axons. Second, locating synapses between connected basket-Purkinje cell pairs is relatively easy because the majority of basket cell synapses are made onto the soma or axon initial segment of Purkinje cells (Palay and Chan-Palay, 1974). This allows us to monitor release from evoked IPSCs in the Purkinje cell while locally applying aspartate to presynaptic boutons. Because action potential (AP)-evoked release is highly sensitive to small changes in ambient calcium (Felmy et al., 2003; Awatramani et al., 2005), it is expected that presynaptic NMDAR activation would have a significant effect on release.

We found that iontophoretic application of aspartate on basket cell axons had no effect on evoked IPSC amplitudes recorded in Purkinje cells. Furthermore, two-photon calcium measurements in basket cell axons did not detect any calcium response following aspartate iontophoresis or glutamate uncaging. These data are not consistent with NMDAR expression on basket cell axons.

\section{Materials and Methods}

Acute parasagittal brain slices were prepared from the cerebella of P8 P18 Sprague Dawley rats. Slices were prepared as previously described (Pugh and Jahr, 2011) in accordance with Oregon Health \& Science University protocols. Slices were superfused with oxygenated ACSF 
$\left(22-24^{\circ} \mathrm{C}\right.$ ) containing the following (in $\mathrm{mm}$ ): $119 \mathrm{NaCl}, 26.2 \mathrm{NaHO}_{3}, 2.5$ $\mathrm{KCl}, 1 \mathrm{NaH}_{2} \mathrm{PO}_{4}, 2 \mathrm{CaCl}_{2}$, and 11 glucose. Five to ten micromolar NBQX and $10 \mu \mathrm{M} \mathrm{D}$-serine were added to the ACSF, and $\mathrm{Mg}^{2+}$ was absent to maximize detection of NMDARs.

Interneurons in the inner third of the molecular layer were identified with gradient-contrast infrared optics and patched using borosilicate pipettes (4-5 M $\Omega$ ) containing the following (in $\mathrm{mM}$ ): $134 \mathrm{KCl}, 4 \mathrm{MgCl}_{2}$, 10 HEPES, 4 Na-ATP, 0.5 Na-GTP, 0.02-0.05 Alexa Fluor 594, 0.2 Fluo5F. Ten millimolar GABA was included to minimize rundown of IPSCs. Basket cells were identified by the observation of axon collaterals contacting Purkinje somata. Purkinje cells were targeted for patching (same internal solution without fluorescent dyes) based on the presence of a labeled basket cell axon contacting the soma. Connectivity was tested by evoking APs in the basket cell using a 5-8 ms current injection and recording IPSCs in the Purkinje cell (holding potential at -40 to -50 $\mathrm{mV}$ for a $20-30 \mathrm{mV} \mathrm{Cl}^{-}$driving force). Analog records were filtered at $3-4 \mathrm{kHz}$ and digitized at $20 \mathrm{kHz}$. Data were collected using software written by J.S. Diamond in IgorPro (Wavemetrics).

L-Aspartate and ATP were locally applied by iontophoresis using an Axoclamp-2A amplifier (Molecular Devices). An iontophoretic pipette (70-130 M $\Omega$ ) containing $1 \mathrm{~m}$ L-aspartate, $\mathrm{pH} 8$, or $200 \mathrm{~mm}$ ATP was positioned near $(<10 \mu \mathrm{m})$ the process of interest, and L-aspartate/ATP was ejected by a brief (5-200 ms) $100 \mathrm{nA}$ current. Currents elicited by iontophoresis last $>100 \mathrm{~ms}$, even following a brief current pulse. A -2 $\mathrm{nA}$ backing current was used to limit leakage from the pipette between applications.

Two-photon laser scanning microscopy (2PLSM) and two-photon glutamate uncaging (2PGU) were performed using an Olympus upright microscope and two Ti:sapphire lasers (Coherent). Photomultipliers (H8224 and H1077, Hamamatsu) collected red (R) and green (G) light in both the epifluorescence and transfluorescence pathways. ScanImage software (Pologruto et al., 2003) was used for acquisition. Line scans were performed at $500 \mathrm{~Hz}$. Photobleaching, measured in the red channel, was $<3 \%$ in all experiments. In glutamate uncaging experiments, the recirculating bath solution contained $2.5 \mathrm{~mm}$ 4-methoxy-7-nitroindolinyl (MNI)-glutamate, $500 \mathrm{~nm}$ TTX, $5 \mu \mathrm{M}$ NBQX, $100 \mu \mathrm{m}$ picrotoxin, $3.3 \mathrm{~mm}$ $\mathrm{Ca}^{2+}$, and $0.05 \mathrm{Mg}^{2+}$. Glutamate uncaging was induced by brief $(0.5 \mathrm{~ms})$ laser pulses $(720 \mathrm{~nm})$ adjacent to the process of interest.

Pharmacological agents were from Tocris Cookson (MNI-glutamate, TTX), Invitrogen (Alexa 594, Fluo5F), Ascent Scientific (NBQX), and Sigma (picrotoxin). Data were analyzed using IgorPro and ImageJ (NIH). Statistical significance was determined using paired Student's $t$ tests. A value of $p \leq 0.05$ was considered significant. Data are reported as the mean \pm SE.

\section{Results}

Basket cells in the cerebellar cortex were patch-clamped, and axons were followed using 2PLSM until collateral axons contacting Purkinje somata were identified (Fig. $1 A$ ). To test for activation of NMDARs on basket cell terminals, an iontophoretic pipette containing $1 \mathrm{M}$ aspartate was placed near $(5-10 \mu \mathrm{m})$ varicosities contacting a Purkinje soma (Fig. $1 A$, inset). Internal calcium was measured by line scans across a varicosity, and on alternating interleaved trials aspartate was briefly (5-20 ms) iontophoresed onto the axon. An AP was elicited by somatic current injection at the end of each trial to confirm that dye had diffused into the varicosity and to monitor photobleaching/damage. Aspartate produced no change in the average calcium signal measured $100-$ $300 \mathrm{~ms}$ after the onset of iontophoresis (control: $\Delta \mathrm{G} / \mathrm{R}-0.01 \pm$ $0.004 \%$; aspartate: $\Delta \mathrm{G} / \mathrm{R}-0.001 \pm 0.005 \% ; p=0.1, n=15$ ) (Fig. $1 B$ ) or the AP-evoked calcium transient (control: $\Delta \mathrm{G} / \mathrm{R} 0.69 \pm$ $0.09 \%$; aspartate: $\Delta \mathrm{G} / \mathrm{R} 0.68 \pm 0.09 \%$; $p=0.36, n=13$ ) compared with interleaved control sweeps. For each cell, ejection of aspartate was tested by iontophoresis onto the basket cell soma. In every case, this produced depolarization and spiking (Fig. $1 B$, inset).

Iontophoresis was used in these experiments because the aspartate application is localized enough $(\sim 30 \mu \mathrm{m})$ to avoid acti-
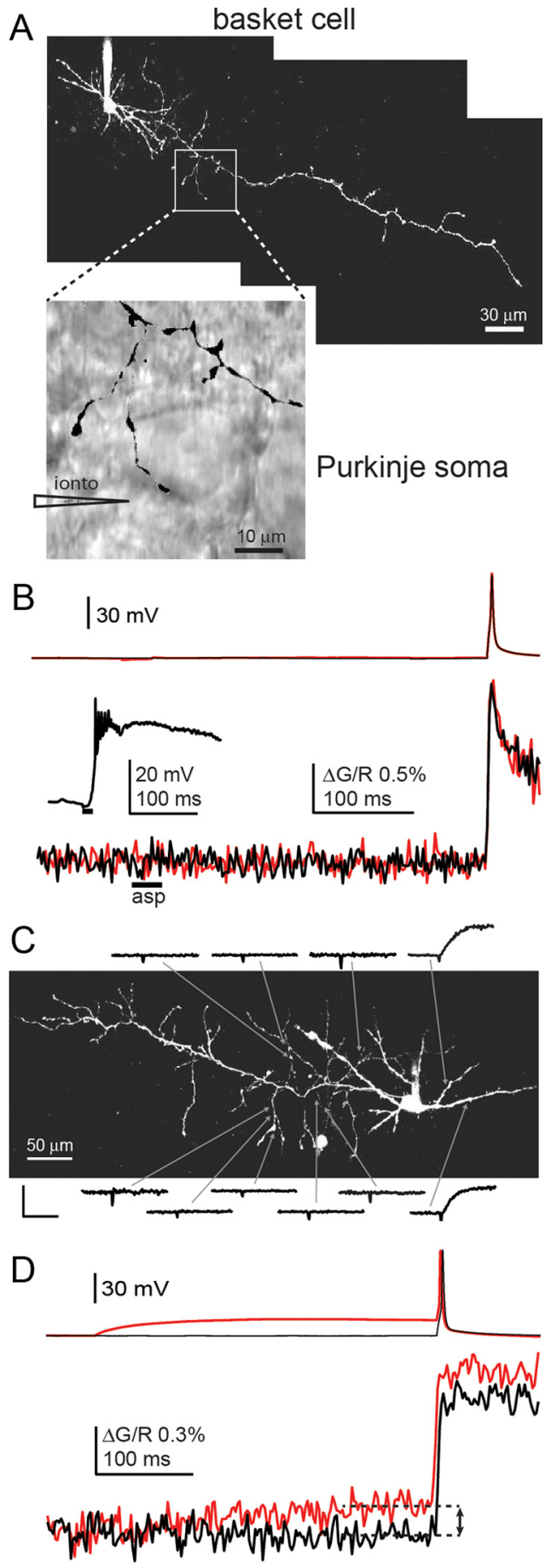

Figure 1. L-Aspartate iontophoresis or glutamate uncaging does not increase axonal calcium in basket cells. $\boldsymbol{A}$, Maximum projection image of a basket cell filled with Alexa Fluor 594. Inset, 0verlaid scanning infrared and fluorescence images showing an axon and Purkinje soma. Iontophoretic pipette position is indicated with triangle. $\boldsymbol{B}$, Membrane potential recorded at the soma (top) and calcium response measured in an axonal varicosity (bottom) in control (black traces) or following iontophoresis of L-aspartate (black bar) onto the axon (red traces). Inset, Membrane potential following iontophoresis of L-aspartate onto the basket cell soma. Same cell as in A. C, Maximum projection image of a basket cell and calcium responses following glutamate uncaging at the locations indicated by the arrows. Calibration: $\Delta G / R 20 \%, 100 \mathrm{~ms}$. D, Membrane potential recorded at the soma (top) and calcium response measured in an axonal varicosity (bottom) in control (black traces) or following subthreshold depolarization of the basket cell soma (red traces). 
vation of somatodendritic receptors, but broad enough to ensure that high concentrations of L-aspartate reach presynaptic varicosities near a target Purkinje soma. However, the spatiotemporal concentration profile is much slower and broader than that of neurotransmitter in the synaptic cleft. To more closely mimic the actions of synaptically released neurotransmitter and to ensure high agonist concentrations at a target varicosity, we used 2PGU. We uncaged glutamate at 40 axonal varicosities on five basket cells and failed to observe any calcium responses (average $\Delta \mathrm{G} / \mathrm{R}$ : $-0.01 \pm 0.02 \% ; p=0.27$. Uncaging glutamate near the dendrites of the same cells always produced a robust response $(\Delta \mathrm{G} / \mathrm{R}$ : $18.4 \pm 2.9 \%$; $p<0.0001, n=13$ ) (Fig. $1 C$ ). However, the opening of a single axonal NMDAR may produce only a modest rise in intracellular calcium, which we were unable to detect. To demonstrate the sensitivity of the 2PLSM used in these experiments, we imaged axonal varicosities during subthreshold somatic depolarizations, which are expected to open only a few voltagegated calcium channels (VGCCs) (see Discussion). Somatic depolarizations increased the axonal calcium signal only modestly compared with interleaved control sweeps, though this increase was highly significant $(\Delta \mathrm{G} / \mathrm{R}: 0.052 \pm 0.015 \% ; p=0.003$, $n=19$; average distance from the soma, $117.8 \pm 20.3 \mu \mathrm{m}$ ) (Fig. $1 D)$. This suggests that microscope sensitivity does not limit our ability to detect NMDAR-mediated calcium transients.

However, we cannot completely rule out the possibility that we are unable to detect calcium entry through single NMDARs or through NR3-containing receptors that are less permeable to calcium. We therefore directly tested for effects of presynaptic NMDAR activation on vesicle release by recording from synaptically connected basket-Purkinje cell pairs. By patching Purkinje cells that appeared to be contacted by a labeled basket cell axon (Fig. 1A), we obtained a connection rate of $93 \%$. The high connection rate, compared with previous reports of basket-Purkinje cell pairs ( $30 \%$; Sakaba, 2008), suggests that visually identified contacts are in fact functional basket-Purkinje cell synapses. IPSCs, recorded in Purkinje cells, were elicited by pairs of APs ( 25 ms interstimulus interval) in basket cells. On alternating interleaved trials, aspartate was iontophoresed onto the basket cell axon $100 \mathrm{~ms}$ before the first action potential. Aspartate had no effect on the average IPSC amplitude (control: $65.8 \pm 18.2 \mathrm{pA}$; aspartate: $67.2 \pm 20.2 \mathrm{pA} ; p=0.59, n=7$ ) (Fig. $2 A, D$ ). Because receptor expression is often developmentally regulated, and DPI in Purkinje cells is more robust at younger ages (Duguid et al., 2004), we repeated these experiments in P8-P11 animals. There was still no effect of aspartate on evoked IPSC amplitudes (control: $62.6 \pm 27.1 \mathrm{pA}$; iontophoresis: $62.7 \pm 25.3 ; p=0.97, n=4)$ or calcium signals recorded from basket cell varicosities (control: $\Delta \mathrm{G} / \mathrm{R},-0.008 \pm 0.019 \%$; aspartate: $\Delta \mathrm{G} / \mathrm{R},-0.002 \pm 0.009 ; p=$ $0.65, n=12$ ). These data suggest that either functional NMDARs are not expressed on basket cell terminals or they have no direct effect on transmitter release.

IPSCs recorded in Purkinje cells had a paired pulse ratio near $1(0.97 \pm 0.07, n=14)$, possibly indicating a high basal release probability. This raises the possibility that NMDARs are expressed on basket cell terminals but their activation fails to increase release because it is already near the upper limit. To rule out this possibility, we attempted to increase release with subthreshold somatic depolarizations before APs (Fig. 2 B, left). Subthreshold depolarizations increased IPSCs by $12.4 \pm 4.8 \%$ ( $p=$ $0.004, n=14$; average distance between cells, $91.3 \pm 8.2 \mu \mathrm{m}$ ) (Fig. $2 B, D$ ), suggesting that release probability at these synapses is sensitive to small changes in intracellular calcium. Furthermore, in four pairs, increasing bath calcium from 2 to $4 \mathrm{~mm}$ more

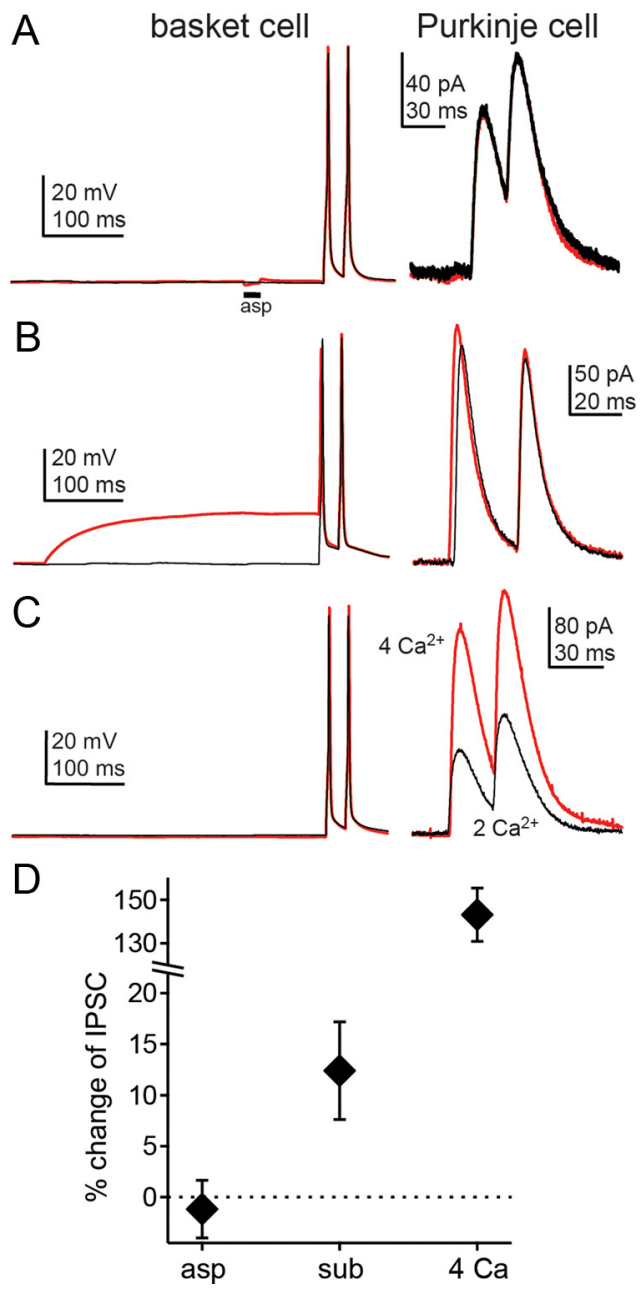

Figure 2. L-Aspartate does not increase release at basket-Purkinje cell synapses. A-C, ACtion potentials evoked in a basket cell (left) and IPSCS recorded in a connected Purkinje cell (right) in control (black traces) and following iontophoresis of $\mathrm{L}$-aspartate onto the basket cell axon $(\boldsymbol{A}$, red traces), subthreshold depolarization of the basket cell soma ( $\boldsymbol{B}$, red traces), or bath application of $4 \mathrm{~mm} \mathrm{Ca}^{2+}$ (C, red traces). D, Average change of IPSCS.

than doubled IPSC amplitudes, with an average increase of $143 \pm$ $12 \%$ (Fig. 2C,D). These data indicate that an NMDAR-mediated increase in transmitter release is not limited by a high basal release probability or postsynaptic $\mathrm{GABA}_{\mathrm{A}}$ receptor saturation.

These experiments assume that basket-Purkinje cell pairs are connected by synapses on or near the Purkinje cell body. However, basket cells also make some axodendritic synapses in the molecular layer that may not be reached by iontophoresis near the Purkinje cell layer. To test this possibility, we used iontophoresis of ATP to activate purinergic receptors expressed on basket cell axons (Deitmer et al., 2006; Donato et al., 2008). ATP reduced IPSC amplitudes in Purkinje cells by $14.3 \pm 5.9 \%(p=$ $0.036, n=7$ ) compared with interleaved control sweeps (Fig. $3 B, D)$. This effect was blocked by $30 \mu \mathrm{M}$ pyridoxal-phosphate- 6 azophenyl-2', $4^{\prime}$-disulfonate (PPADS) $(2.5 \pm 6.5 \%$ reduction; $p=0.78, n=6)$ and recovered following washout $(13.6 \pm 7.4 \%$ reduction; $p=0.05, n=6$ ) (Fig. $3 D$ ). While there was no change in axonal calcium following iontophoresis (control: $\Delta \mathrm{G} / \mathrm{R}$ $-0.011 \pm 0.004 \%$; ATP: $\Delta \mathrm{G} / \mathrm{R}-0.012 \pm 0.007 \%$; $p=0.81, n=$ 9), there was a reliable decrease in the AP-evoked calcium transient (control: $\Delta \mathrm{G} / \mathrm{R} 0.84 \pm 0.09 \%$; ATP: $\Delta \mathrm{G} / \mathrm{R} 0.79 \pm 0.08 \%$; $p=0.02$ ) (Fig. $3 A, C$ ), consistent with activation of $\mathrm{P} 2 \mathrm{Y}$ receptors and modulation of VGCCs (Abe et al., 2003; Gerevich et al., 
A
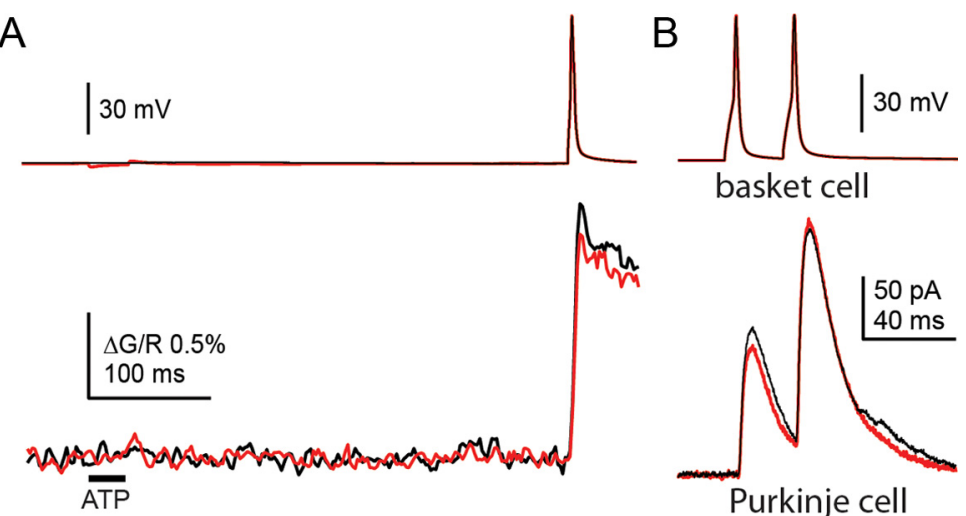

basket cell

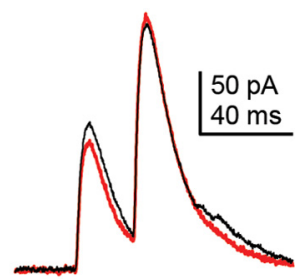

Purkinje cell

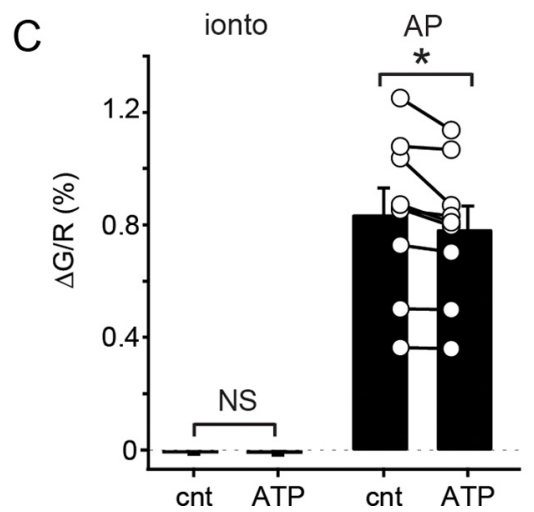

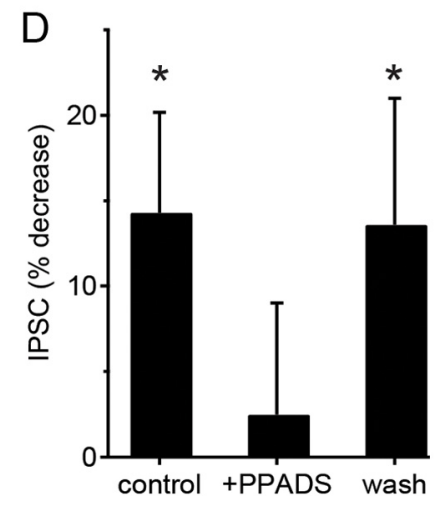

Figure 3. ATP iontophoresis reduces AP-evoked calcium transients and transmitter release. A, Somatic membrane potential (top) and axonal calcium response (bottom) in control (black traces) or following iontophoresis of ATP (black bar) onto the basket cell axon (red traces). $\boldsymbol{B}$, Action potentials evoked in a basket cell (top) and IPSCs recorded in a connected Purkinje cell (bottom) in control (black traces) or following iontophoresis of ATP onto the basket cell axon (red traces). C, Average calcium responses $(\Delta G / R)$ measured $100-300 \mathrm{~ms}$ after the onset of iontophoresis (ionto) or after an AP in control conditions or following iontophoresis of ATP. Individual cells plotted as circles and connecting lines. D, Percentage decrease of IPSC amplitudes following iontophoresis of ATP in control, $30 \mu \mathrm{M}$ PPADS, and washout.

2004). Somatodendritic iontophoresis of ATP depolarized basket cells, suggesting that $\mathrm{P} 2 \mathrm{X}$ receptors may be expressed on the soma while P2Y receptors are expressed on axon. These data indicate that at least a significant fraction of connections between basketPurkinje cell pairs are within range of an iontophoretic pipette placed near the Purkinje soma. This suggests that iontophoresis of aspartate should, likewise, reach at least many of the axonal varicosities connecting basket-Purkinje cell pairs. The lack of calcium responses in axonal varicosities or modulation of IPSC amplitudes leads to the conclusion that NMDARs are either not expressed in basket cell terminals or are expressed at such low densities that they have no discernable effect on transmitter release.

\section{Discussion}

We find no evidence of functional NMDAR expression on basket cell axons. Application of NMDAR agonists failed to produce a change in either axonal calcium, measured by 2PLSM, or transmitter release, measured by IPSC amplitudes in synaptically coupled Purkinje cells. Our failure to detect NMDARs did not result from saturation of release, as subthreshold somatic depolarizations and raised external calcium increased transmitter release. Nor is it likely that aspartate failed to reach basket cell boutons, as iontophoresis of ATP reduced release probability by activating presynaptic purinergic receptors and aspartate evoked large NMDAR-mediated responses at the soma. In this study, we used P8-P18 animals to match those used in previous studies report- ing expression of presynaptic NMDARs in MLIs. Axonal NMDARs may be expressed in older animals, though we are not aware of any evidence suggesting this.

Previous studies of presynaptic NMDARs, including those in cerebellar interneurons, have measured evoked or spontaneous synaptic events before and during bath application of NMDAR agonists or antagonists (Glitsch and Marty, 1999; Sjöström et al., 2003; Brasier and Feldman, 2008; Glitsch, 2008; Larsen et al., 2011). However, distinguishing between activation of axonal receptors and activation of somatodendritic receptors is difficult using global drug application. Activation of somatodendritic receptors and subsequent subthreshold depolarization of the axon can produce many of the effects frequently attributed to presynaptic NMDARs, including increased frequency of spontaneous events (Glitsch and Marty, 1999; Christie et al., 2011), increased ambient calcium in axonal varicosities (Christie and Jahr, 2008; Christie et al., 2011), and larger evoked responses due to increased excitability of axons (Pugh and Jahr, 2011) or increased release probability (Alle and Geiger, 2006; Shu et al., 2006; Pugh and Jahr, 2011). Other studies have demonstrated presynaptic forms of LTD that are blocked by the inhibition of NMDARs, suggesting the expression of presynaptic NMDARs (Sjöström et al., 2003; Bender et al., 2006; Rodríguez-Moreno et al., 2011). However, these studies need to be followed up with direct recordings of presynaptic NMDAR-mediated currents or calcium responses. Duguid and Smart (2004) showed transient potentiation of inhibitory synapses onto Purkinje cells; however, in this case, the effects of NMDAR activation on spontaneous IPSCs developed over several minutes and lasted 5-10 min, not consistent with a straightforward effect of calcium entry or depolarization on release. While these studies demonstrate NMDAR-dependent long-term effects on release, it is not clear that NMDAR-mediated currents in presynaptic terminals directly influence release. The present study is the first we are aware of that combines measurement of evoked release using synaptically coupled pairs of neurons and local application of NMDAR agonist onto axonal boutons.

\section{NR3 subunit-containing receptors}

NMDARs show a great deal of molecular diversity, including eight NR1 subunit splice variants, four NR2 subunits, and two NR3 subunits. The subunit composition of NMDARs determines the kinetics, sensitivity to $\mathrm{Mg}^{+}$block, and calcium permeability of the receptors. NR3 subunit expression has been reported in molecular layer interneurons (Wong et al., 2002), the incorporation of which into NMDARs substantially reduces calcium permeability (Matsuda et al., 2002). This raises the possibility that NR3-containing NMDARs are expressed in basket cell axons, as has been reported in cortical pyramidal cell axons (Larsen et al., 2011), rendering them difficult to detect with calcium measure- 
ments. However, activation of NR3-containing receptors would still be expected to depolarize the synaptic bouton leading to increased release (Awatramani et al., 2005). We did not detect any change in transmitter release following aspartate application, suggesting that either NR3-containing NMDARs are not expressed in axons or the NMDA-mediated currents produced are insufficient to alter release. This does not rule out downstream signaling through presynaptic NR3-containing NMDARs altering long-term transmitter release, a possibility suggested by the slow onset and long duration of NMDAR-mediated effects seen by Duguid and Smart (2004).

\section{Two-photon microscope sensitivity}

Our ability to measure NMDAR-mediated calcium influx in axons is limited by the sensitivity of the 2PLSM. We were able to consistently measure axonal calcium responses during somatic subthreshold depolarizations, demonstrating the ability to measure small calcium responses, but how do these responses compare to those expected from a single NMDAR? Previous reports estimated that 18-45 VGCCs open per AP per release site (Koester and Sakmann, 2000; Luo et al., 2011). Calcium responses in basket cell axons during subthreshold depolarizations were approximately one-sixteenth the size of AP-evoked responses. Assuming 45-50 calcium channels open per AP, then subthreshold depolarization-evoked calcium responses represent the opening of approximately three calcium channels. NMDARs and VGCCs have similar calcium permeability (Hille, 2001), but NMDARs have $\sim 10$-fold greater open time (Lester et al., 1990) and hence, a 10 -fold greater calcium influx, suggesting that $\mathrm{Ca}^{2+}$ influx through a single NMDAR should be readily detectable. It is therefore unlikely that detection of even single presynaptic $\mathrm{Ca}^{2+}$ permeable NMDARs was limited by microscope sensitivity.

\section{Purinergic receptors}

Purinergic receptors are categorized as either ionotropic P2X receptors or metabotropic P2Y receptors. Previous reports using bath application of specific agonist and antagonists suggest that both are expressed on MLI axons (Deitmer et al., 2006; Donato et al., 2008). However, in this study, axonal iontophoresis of ATP appeared to only activate $\mathrm{P} 2 \mathrm{Y}$ receptors. $\mathrm{P} 2 \mathrm{X}$ receptors are calcium permeable and depolarizing, inconsistent with both the lack of change in intracellular calcium or the reduced transmitter release observed following ATP application. P2Y receptors have been shown to modulate VGCCs and vesicle release (Abe et al., 2003; Gerevich et al., 2004), consistent with our findings. Iontophoresis of ATP onto the soma or dendrites of basket cells depolarized the soma, raising the possibility that bath application of $\mathrm{P} 2 \mathrm{X}$ receptor agonists or antagonists altered release by modulating somatodendritic rather than axonal $\mathrm{P} 2 \mathrm{X}$ receptors in previous studies.

We used ATP iontophoresis to demonstrate that this technique can deliver agonist in sufficient concentrations to synaptic connections between basket-Purkinje cell pairs. This approach assumes that NMDA and $\mathrm{P} 2 \mathrm{Y}$ receptors have similar affinities for aspartate and ATP, respectively. While P2Y receptors have a higher affinity for ATP $(2 \mu \mathrm{M})$ (Bogdanov et al., 1998) than NMDARs have for L-aspartate $(17 \mu \mathrm{M})$ (Patneau and Mayer, 1990), it is unlikely that this difference is great enough to significantly change the spatial extent of receptor activation, especially considering a higher concentration of aspartate was used (1 M aspartate, $200 \mathrm{~mm}$ ATP).

Modulation of synaptic function by presynaptic receptors is an important aspect of neural communication. Many types of ionotropic receptors are expressed in presynaptic terminals where they can modulate vesicle release (for review, see MacDermott et al., 1999), and potentially even influence action potential initiation at the axon initial segment (Pugh and Jahr, 2011). However, despite a growing number of reports suggesting presynaptic expression of NMDARs, we are unable to find direct evidence of their expression at this synapse.

\section{References}

Abe M, Endoh T, Suzuki T (2003) Extracellular ATP-induced calcium channel inhibition mediated by $\mathrm{P} 1 / \mathrm{P} 2 \mathrm{Y}$ purinoceptors in hamster submandibular ganglion neurons. Br J Pharmacol 138:1535-1543.

Alle H, Geiger JR (2006) Combined analog and action potential coding in hippocampal mossy fibers. Science 311:1290-1293.

Awatramani GB, Price GD, Trussell LO (2005) Modulation of transmitter release by presynaptic resting potential and background calcium levels. Neuron 48:109-121.

Bender VA, Bender KJ, Brasier DJ, Feldman DE (2006) Two coincidence detectors for spike timing-dependent plasticity in somatosensory cortex. J Neurosci 26:4166-4177.

Bliss TV, Collingridge GL (1993) A synaptic model of memory: long-term potentiation in the hippocampus. Nature 361:31-39.

Bogdanov YD, Wildman SS, Clements MP, King BF, Burnstock G (1998) Molecular cloning and characterization of rat P2Y4 nucleotide receptor. Br J Pharmacol 124:428-430.

Brasier DJ, Feldman DE (2008) Synapse-specific expression of functional presynaptic NMDA receptors in rat somatosensory cortex. J Neurosci 28:2199-2211.

Christie JM, Jahr CE (2008) Dendritic NMDA receptors activate axonal calcium channels. Neuron 60:298-307.

Christie JM, Jahr CE (2009) Selective expression of ligand-gated ion channels in L5 pyramidal cell axons. J Neurosci 29:11441-11450.

Christie JM, Chiu DN, Jahr CE (2011) Ca2+-dependent enhancement of release by subthreshold somatic depolarization. Nat Neurosci 14:62-68.

Clark BA, Cull-Candy SG (2002) Activity-dependent recruitment of extrasynaptic NMDA receptor activation at an AMPA receptor-only synapse. J Neurosci 22:4428-4436.

Deitmer JW, Brockhaus J, Casel D (2006) Modulation of synaptic activity in Purkinje neurons by ATP. Cerebellum 5:49-54.

Donato R, Rodrigues RJ, Takahashi M, Tsai MC, Soto D, Miyagi K, Villafuertes RG, Cunha RA, Edwards FA (2008) GABA release by basket cells onto Purkinje cells, in rat cerebellar slices, is directly controlled by presynaptic purinergic receptors, modulating $\mathrm{Ca}^{2+}$ influx. Cell Calcium 44:521-532.

Duguid IC, Smart TG (2004) Retrograde activation of presynaptic NMDA receptors enhances GABA release at cerebellar interneuron-Purkinje cell synapses. Nat Neurosci 7:525-533.

Duguid IC, Pankratov Y, Moss GW, Smart TG (2007) Somatodendritic release of glutamate regulates synaptic inhibition in cerebellar Purkinje cells via autocrine mGluR1 activation. J Neurosci 27:12464-12474.

Felmy F, Neher E, Schneggenburger R (2003) Probing intracellular calcium sensitivity of transmitter release during synaptic facilitation. Neuron 37:801-811.

Gerevich Z, Borvendeg SJ, Schröder W, Franke H, Wirkner K, Nörenberg W, Fürst S, Gillen C, Illes P (2004) Inhibition of N-type voltage-activated calcium channels in rat dorsal root ganglion neurons by $\mathrm{P} 2 \mathrm{Y}$ receptors is a possible mechanism of ADP-induced analgesia. J Neurosci 24:797-807.

Glitsch MD (2008) Calcium influx through N-methyl-D-aspartate receptors triggers GABA release at interneuron-Purkinje cell synapse in rat cerebellum. Neuroscience 151:403-409.

Glitsch M, Marty A (1999) Presynaptic effects of NMDA in cerebellar Purkinje cells and interneurons. J Neurosci 19:511-519.

Hille B (2001) Ion channels of excitable membranes. Sunderland, MA: Sinauer Associates.

Koester HJ, Sakmann B (2000) Calcium dynamics associated with action potentials in single nerve terminals of pyramidal cells in layer $2 / 3$ of the young rat neocortex. J Physiol 529:625-646.

Larsen RS, Corlew RJ, Henson MA, Roberts AC, Mishina M, Watanabe M, Lipton SA, Nakanishi N, Pérez-Otaño I, Weinberg RJ, Philpot BD (2011) NR3A-containing NMDARs promote neurotransmitter release and spike timing-dependent plasticity. Nat Neurosci 14:338-344. 
Lester RA, Clements JD, Westbrook GL, Jahr CE (1990) Channel kinetics determine the time course of NMDA receptor-mediated synaptic currents. Nature 346:565-567.

Luo F, Dittrich M, Stiles JR, Meriney SD (2011) Single-pixel optical fluctuation analysis of calcium channel function in active zones of motor nerve terminals. J Neurosci 31:11268-11281.

MacDermott AB, Role LW, Siegelbaum SA (1999) Presynaptic ionotropic receptors and the control of transmitter release. Annu Rev Neurosci 22:443-485.

Matsuda K, Kamiya Y, Matsuda S, Yuzaki M (2002) Cloning and characterization of a novel NMDA receptor subunit NR3B: a dominant subunit that reduces calcium permeability. Brain Res Mol Brain Res 100:43-52.

McGuinness L, Taylor C, Taylor RD, Yau C, Langenhan T, Hart ML, Christian H, Tynan PW, Donnelly P, Emptage NJ (2010) Presynaptic NMDARs in the hippocampus facilitate transmitter release at theta frequency. Neuron 68:1109-1127.

Palay SL, Chan-Palay V (1974) Cerebellar cortex: cytology and organization. New York: Springer.

Patneau DK, Mayer ML (1990) Structure-activity relationships for amino acid transmitter candidates acting at $N$-methyl-D-aspartate and quisqualate receptors. J Neurosci 10:2385-2399.
Pologruto TA, Sabatini BL, Svoboda K (2003) ScanImage: flexible software for operating laser scanning microscopes. Biomed Eng Online 2:13.

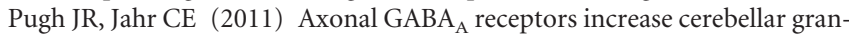
ule cell excitability and synaptic activity. J Neurosci 31:565-574.

Rodríguez-Moreno A, Kohl MM, Reeve JE, Eaton TR, Collins HA, Anderson HL, Paulsen O (2011) Presynaptic induction and expression of timingdependent long-term depression demonstrated by compartment-specific photorelease of a use-dependent NMDA receptor antagonist. J Neurosci 31:8564-8569.

Sakaba T (2008) Two Ca(2+)-dependent steps controlling synaptic vesicle fusion and replenishment at the cerebellar basket cell terminal. Neuron 57:406-419.

Shu Y, Hasenstaub A, Duque A, Yu Y, McCormick DA (2006) Modulation of intracortical synaptic potentials by presynaptic somatic membrane potential. Nature 441:761-765

Sjöström PJ, Turrigiano GG, Nelson SB (2003) Neocortical LTD via coincident activation of presynaptic NMDA and cannabinoid receptors. Neuron 39:641-654.

Wong HK, Liu XB, Matos MF, Chan SF, Pérez-Otaño I, Boysen M, Cui J, Nakanishi N, Trimmer JS, Jones EG, Lipton SA, Sucher NJ (2002) Temporal and regional expression of NMDA receptor subunit NR3A in the mammalian brain. J Comp Neurol 450:303-317. 